\title{
Neuropsychiatry: a different approach or a different clientele?
}

\author{
Bruce D. M. Scheepers, Jonathan M. Bird and Daniel G. Rogers
}

\begin{abstract}
Reauls of a rotroepective aurvey of the recosons for

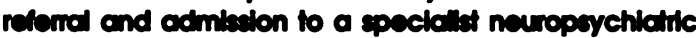
hosplital are presented in on efiot to addreses the uncertalutiles which oxid regareling the noture of the conditions treeted by this subepectetty. Tho realls indicets that a wide renges of both neurological and poychicitic conctilions ore treated, but the poper augesets that boundertes between thees two epectatities are lowedy conceptual and that the diverentioting pinctive in the proctice of neuropoychicity is mainty philosophiced.
\end{abstract}

Neuropsychiatry, as a distinct and separate subspecialty, has gained increasing support in Europe and in the USA over recent years. The British Neuropsychiatry Association has been in existence since 1988 and counts, among its 380 members, 188 psychiatrists. A recent survey of members of both the British and the American Neuropsychiatric Associations suggests that not only do members consider many of the conditions treated to be unique, but neuropsychiatry is also felt to embody a distinctive philosophical approach (Lishman. 1992).

Neuropsychiatry is claimed to bridge the gap between neurology and psychiatry (Reynolds \& Trtmble, 1989) but it is uncertain to what extent the conditions seen in a neuropsychiatry out-patient clinic or inpatient unit differ from those seen in a general psychiatry or neurology setting. Lishman produces figures which indicate that $49 \%$ of patients referred to the Maudsley Neuropsychiatric Unit were suffering from a clear organic psychosyndrome (Lishman, 1992), suggesting that the distinctive practice of this speciality lies in the nature of the conditions treated. Only $10 \%$ of patients had a primary neurological disorder, $22 \%$ a primary psychiatric condition and a further $20 \%$ had overlapping or uncertain diagnoses. Some patients had more than one diagnosis in this series.
There is no information in the literature to reflect the reasons why referring agents choose to refer a paricular patient to a specialist neuropsychiatric unit rather than to elther neurology or psychiatry, or indeed which patients are referred by neurologists, psychiatrists or other specialists.

Because of the rarity of specialist neuropsychiatric resources in this country it is to be expected that referrals to such a unit will not only reflect the needs of the referring agent, but also, to a certain degree, the special interests of the neuropsychiatry practitioners. The Burden Neurological Hospital is the only specialist neorupsychiatric hospital in the country and an analysis of referrals and admissions to this institution would therefore go someway in identifying the nature of the service provided by this speciality. Results of a retrospective survey of all new referrals and admissions to the hospital over a stx-month period are presented.

\section{The study}

The medical notes of all new out-patient attenders during the period 1 April 1992 to 30 September 1992 were scrutinized to determine the reason for referral. Over $75 \%$ of referrals to the hospital are from general practitioners with the remainder being evenly distributed between neurologists, psychiatrists and neurosurgeons. This does not adequately reflect the 'tertlary' nature of referrals, nevertheless it is recognized that in many instances the patient had already been seen by other spectalists.

The information regarding reason for referral was usually clearly documented in the referrer's letter, but in some instances where this was unclear or a number of different reasons were documented, a single main reason was sought and extracted. Additional demographic data were recorded. 
Admissions to the hospital were also analysed as it is recognized that referrers' perception of the patients' problems as well as what they percetved neuropsychiatry had to offer was not necessarily a reflection of the type of patient admitted or the views and philosophy of the neuropsychiatrists themselves. Admissions are always at the request of one of the consultant neuropsychiatrists, usually from their outpatient clinics. The reason for admission is frequently not clearly stated although it is often indicated in the discharge summary to the referring agent. Although discharge diagnoses according to ICD-9 criterla were recorded, it was felt that this information did not accurately reflect the information which we were seeking. It was also evident that ICD-9 is not an adequate classification system for many neuropsychiatric conditions. Because of these difficulties, for the admission data a maximum of two reasons was allowed.

\section{Finding}

New out-patients' referral data

A total of 182 new out-patient records over the stx-month period were analysed. It was discovered that 73 'new' referrals had previously been associated with the hospital, but for various reasons had been discharged from follow-up or had falled to keep further appointments. In most instances, the only reason for referral specifically to neuropsychiatry, on this occasion, was previous contact with the patient. It was therefore felt that these cases should be excluded from the study as they would not adequately reflect the reason why the referral was made to neuropsychiatry rather than to neurology or psychiatry. The total number of patients therefore included as new referrals was thus 109.

Although the Burden Neurological Hospital is a tertiary referral centre, $77 \%$ of referrals were from GPs with $9 \%$ from psychiatrists, $8 \%$ from neurologists and $6 \%$ from neurosurgeons. This does not reflect the number of GP referrals which were at the suggestion of, or in addition to, another specialist service.

Table 1 indicates the reason why the referring agent requested a first out-patient consultation together with the percentage of the total represented by each group. The largest single group of referrals were patients
Table 1. New out-patient referrals $(n=109)$

\begin{tabular}{|c|c|}
\hline $\begin{array}{l}\text { Epllepsy (32\%) } \\
\text { Query now epllepsy } \\
\text { Refractory epllepsy } \\
\text { Epllepsy with eplsodlc dyscontrol } \\
\text { Epllepsy with poychosts } \\
\text { Epllepsy with depression }\end{array}$ & $\begin{array}{l}=15 \\
=18 \\
=1 \\
=1 \\
=1\end{array}$ \\
\hline $\begin{array}{l}\text { Migraine (8\%) } \\
\text { Possible new migraine } \\
\text { Refractory migraine }\end{array}$ & $\begin{array}{l}=4 \\
=5\end{array}$ \\
\hline $\begin{array}{l}\text { Sleep disorder (6\%) } \\
\text { Narcolepsy } \\
\text { Sleep apnoed } \\
\text { Insomnia }\end{array}$ & $\begin{array}{l}=4 \\
=1 \\
=1\end{array}$ \\
\hline $\begin{array}{l}\text { Chronk pain (3\%) } \\
\text { Perineal pain } \\
\text { Backpain }\end{array}$ & $\begin{array}{l}=1 \\
=2\end{array}$ \\
\hline $\begin{array}{l}\text { Other (5\%) } \\
\text { Post meningltts } \\
\text { Post-tumour surgery } \\
\text { Aggresston } \\
\text { Mental handicap for ADL assessment }\end{array}$ & $\begin{array}{l}=1 \\
=1 \\
=2 \\
=1\end{array}$ \\
\hline $\begin{array}{l}\text { Psychlatry (4\%) } \\
\text { Depression with somattzation } \\
\text { Vlsual hallucinations } \\
\text { Eating disorder }\end{array}$ & $\begin{array}{l}=2 \\
=1 \\
=1\end{array}$ \\
\hline $\begin{array}{l}\text { Neurology (6\%) } \\
\text { Sensory deficlt } \\
\text { Dizziness } \\
\text { Muscular weakness }\end{array}$ & $\begin{array}{l}=2 \\
=3 \\
=1\end{array}$ \\
\hline $\begin{array}{l}\text { Hysterla (9\%) } \\
\text { Dissoclative amnesia } \\
\text { NEAD } \\
\text { Epllepsy with NEAD }\end{array}$ & $\begin{array}{l}=2 \\
=6 \\
=2\end{array}$ \\
\hline $\begin{array}{l}\text { Movement clsorder (16\%) } \\
\text { Parkinsons } \\
\text { Dystonla (torticolls, etc) } \\
\text { Dyskinesia }\end{array}$ & $\begin{array}{r}=5 \\
=10 \\
=3\end{array}$ \\
\hline $\begin{array}{l}\text { Brain infury (7\%) } \\
\text { Cognittive problems } \\
\text { Behoviour problems }\end{array}$ & $\begin{array}{l}=4 \\
=4\end{array}$ \\
\hline $\begin{array}{l}\text { Memory clsorder (4\%) } \\
\text { Dementia/cognittve defictt }\end{array}$ & $=4$ \\
\hline
\end{tabular}

with epilepsy or possible epilepsy representing almost one third of all referrals. It should be noted that the figures quoted by Lishman (Lishman, 1992) include very few epllepsy patients, as an epllepsy clinic at the Maudsley provides a separate facllity for these referrals.

Movement disorders, migraine, hysteria and the sequelae of head injury were other 
significant diagnostic groups. A surprise finding was the small number of referrals of patients with a primary psychiatric problem and the relattvely high proportion of patients with primary neurological problems. This may well reflect the length of the waiting lists for particular services within the region or the fact that various research drug trials facilitated promptness of consultation by way of a fast track' clinic. It is, for example, unclear why such a large number of migraine patients should require a tertlary referral, especially in new or suspected cases.

There was little evidence of patients being referred with specific organic psychosyndromes and in particular dementia, which contrasts starkly with the Maudsley figures, although this survey reflected the referrer's diagnosis or diagnostic dilemma rather than a final neuropsychiatric diagnosis. It should furthermore be recognised that a specialist service of this nature will understandably attract referrals relating to specific interests of the neuropsychiatrist practitioners and this for instance probably accounts for the high incidence of movement disorder referrals to the Burden.

What was most noticeable during the course of this study was the difficulty in diagnostically labelling the presenting problems and of grouping reasons for referral into diagnostic categories. This reinforces the impression that the classification systems and nosology used in psychiatry do not transfer readily to neurology or vice versa.

Of those patients referred directly by neurologists ( $n=10), 40 \%$ had non-eplleptic attack disorders and $40 \%$ had a movement disorder. Of patients referred directly by psychiatrists $(n=13), 31 \%$ had behaviour problems of unknown aetlology or associated with either epilepsy or brain injury, $23 \%$ had sleep disorders and $23 \%$ had movement disorders. When the actual referral came from the general practitioner, it was not possible to ascertain the reason why the neurologist or psychiatrist suggested referral, or was unable to provide appropriate treatment themselves if they had been involved. It must be assumed that the GP's reason for referral would reflect the opinion of other specialists who had assessed the patient.

Of new out-patient referrals, $63 \%$ were given further follow-up appointments or admitted and for the other referrals, the referring agent was advised and the patient discharged.
Table 2. Reason for admission ( $n=74)$

\begin{tabular}{|c|c|}
\hline $\begin{array}{l}\text { Psychlathy (26\%) } \\
\text { Depression } \\
\text { Anxlety } \\
\text { OCD } \\
\text { Psychosis } \\
\text { Panic attacks }\end{array}$ & $\begin{array}{l}=10 \\
=6 \\
=8 \\
=2 \\
=1\end{array}$ \\
\hline $\begin{array}{l}\text { Epllepsy (26\%) } \\
\text { Uncontrolled } \\
\text { Medication change } \\
\text { New epllepsy }\end{array}$ & $\begin{array}{l}=18 \\
=7 \\
=3\end{array}$ \\
\hline $\begin{array}{l}\text { Epllepsy surgery (5\%) } \\
\text { Sphenoldal recording and Wada test } \\
\text { or monltoring }\end{array}$ & $=5$ \\
\hline $\begin{array}{l}\text { Brain injury (14\%) } \\
\text { Cogniltive problems } \\
\text { Behoviour problems } \\
\text { CO polsoning-global problems }\end{array}$ & $\begin{array}{l}=8 \\
=5 \\
=1\end{array}$ \\
\hline $\begin{array}{l}\text { Hysterla (13\%) } \\
\text { Non eplleptic attack disorder (NEAD) } \\
\text { Paralysts } \\
\text { Pain syndrome }\end{array}$ & $\begin{array}{l}=9 \\
=1 \\
=3\end{array}$ \\
\hline $\begin{array}{l}\text { Movement disorder (8\%) } \\
\text { Parkinsons } \\
\text { Dystonias } \\
\text { Dyskinesias }\end{array}$ & $\begin{array}{l}=4 \\
=2 \\
=2\end{array}$ \\
\hline $\begin{array}{l}\text { Behoviour problems (5\%) } \\
\text { Eplsodlc dyscontrol } \\
\text { Mental handicap }\end{array}$ & $\begin{array}{l}=4 \\
=1\end{array}$ \\
\hline $\begin{array}{l}\text { Memory disorder (3\%) } \\
\text { Korsakoff dementia } \\
\text { Frontal lobe dementia }\end{array}$ & $\begin{array}{l}=1 \\
=2\end{array}$ \\
\hline
\end{tabular}

\section{Admission data}

Seventy-four patients were admitted over the six-month period. All admissions were included in the survey rather than 'new' admissions and the average length of admission was 57.3 days. Three distinct admission periods were identiflable with most patients staying less than six weeks, a group of patients with admissions of approximately three months and the final group requiring longer-stay treatment of over six months. Patients included in the study were all admitted within the study period, but not necessarily discharged within the same time period.

Table 2 indicates reason for admission with the percentage of the total which each category represents. A maxdmum of two reasons was allowed for each admission and some overlap is apparent. 
Table 3. Reasons for referral and admission grouped into 'psychiatric' or 'neurological' diagnoses

\begin{tabular}{cc}
\hline Psychlatic referrats $(n=25)$ & $\begin{array}{c}\text { Neurological referrats }(n=84) \\
77 \%\end{array}$ \\
$23 \%$ & Neurological admissions $(n=50)$ \\
Psychiatilic admissions $(n=53)$ & $48.5 \%$ \\
$51.5 \%$ & \\
\hline
\end{tabular}

The most striking finding was the increased number of psychiatric diagnoses for admissions compared with the reasons for out-patient referral. Psychiatric disorders, hysteria or behavioural problems were evident in over $40 \%$ of admissions. Patients with epilepsy remain the largest single diagnostic group of patients admitted.

\section{Comment}

There are various methodological difficulties with a retrospective study of this nature. It is accepted that the identification of a reason for referral or admission made retrospectively from referral or discharge letters will, in certain instances, result in investigator bias as will an arbitrary classification or categorisation system as used in this study. How does one categorise a patient with a first episode of loss of consciousness, thought to be syncopal, but referred specifically to exclude the possibility of epilepsy? In this case, the reason was taken to be 'query new epilepsy' and falls under the category of 'epllepsy'.

It was hoped that avoiding discharge ICD-9 coding would give a clearer impression of the nature of the conditions referred to this speciality, but the problems of nosology, uncertain caseness, medical jargon and unscientific terminology present a major obstacle in attempting to communicate information in a meaningful and scientific way without using a specific diagnostic reference. Ultimately one returns to a common diagnostic classification system, however unsatisfactory, in an effort to draw comparisons and to indicate trends or significance. A single, specific classification system was not used in this study and establishing any significance or drawing specific conclusions will be difficult. Nevertheless the difficulties with diagnostic labelling in neuropsychiatry does raise an interesting debate.

Not all cases of non-epileptic attack disorder are conversion hysteria, nor are all chronic pain syndromes, somatisation disorder.
Certain diagnostic groups such as movement disorders and sleep disorders defy 'neurological' or 'psychiatric' categorisation. Additional problems arise when trying to combine certain groups. Should migraine fall under 'primary neurology' or hysteria under "psychiatry'? If one attempted to avoid all specific diagnostic categories and classified reasons for referral or admission as either 'psychtatric' or 'neurological' based on the referrer's perception, then for admissions there is an almost $50 \%$ split between the two, but for new out-patient referrals over $75 \%$ would be classified as 'neurology' (Table 3).

There could be many reasons for the apparent difference between reasons for referral and presenting problem at admission. One explanation is that there is a discrepancy between the referring agents' perception of what neuropsychiatry does as opposed to the actual nature of neuropsychiatric practice. Another possibility is that the referrer's diagnosis differs from that of the neuropsychiatrist's. For example, a referring diagnosis of chronic pain is ultimately diagnosed as chronic depression or somatoform disorder. It could also represent the fact that 'psychiatric' conditions are more difficult to manage on an out-patient basis than 'neurological' ones and it is recognised that certain 'neurological' conditions, such as migraine, will seldom require admission.

Of direct neurology referrals, $80 \%$ were with either movement disorders or non-eplleptic attacks, which would suggest that neurologists consider that these conditions have some 'psychiatric' basis. Similarly the movement disorders, sleep disorders and behavioural problems referred by psychiatrists were possibly considered to have a 'neurological' basis. The small sample sizes prevent adequate analysis and this interpretation might be unfair. It might merely reflect the fact that these conditions are most approprlately treated by a specialist centre and not that the referring agent felt that the problem was beyond their remit. 


\section{Concluaions}

It is not surprising that the literature has not previously attempted to define or to categorise the nature of the conditions considered to be within the remit of neuropsychiatry. Two different sets of data are presented here which demonstrate the arbitrary differences which exist between neurology and psychiatry and the inadequacies of our classification systems when confronted with neuropsychiatric disorders.

One usually views illness or behavioural disorder either from a neurological or from a psychiatric perspective. Progress in neuroscience and particularly in neuroimaging techniques, neurophysiology, neuropsychology, psychopharmacology and genetics have led to the realisation that many 'functional' psychiatric conditions have a neurological basis. A recent review defines neuropsychlatry as "the clinical disctpline devoted to understanding the neurobiological basis, optimal assessment, natural history and most efficacious treatment of disorders of the nervous system with behavioural mantfestations" (Cummings \& Hegarty, 1994). A neuro-psychilatric perspective includes both psychiatric and neurological parameters without being restricted by nosological and philosophical considerations as to whether the behavioural manifestation is regarded as psychopathology or neuropathology.

Neuropsychiatry considers all behavioural, cognitive and emotional manifestation of psychiatric conditions to result from brain dysfunction, recognising the frequent close correlations to similar manifestations observed in neurological disorders. It does not exclude the mind but recognises that "the brain is the organ of mental life" (Cummings \& Hegarty, 1994). It recognises the soctal, cultural, environmental and psychological precipitants of, and contributors to, brain dysfunction and the possibility of manipulating cerebral function through pharmacological, psychologlcal, behavioural and other mechanisms. From this standpoint the boundarles between neurology and psychiatry become increasingly irrelevant and disease classification becomes conceptual. The specific natures of the individual conditions presented in this paper are inadequately categorised by psychiatric classification systems as all referrals represent behavioural manifestations of disorders of the nervous system.

Despite the methodological and conceptual difficulties associated with the data presented In this paper, it does demonstrate the wide range of conditions treated by neuropsychiatry. What it fails to address, is the nature of the therapeutic interventions applied. There is perhaps an incorrect perception by psychiatrists that neuropsychilatry is involved purely with physical treatment modalities. Therapy at this particular neuropsychiatric centre frequently entalls a combination of psychological and physical interventions although there are a significant number of conditions where a purely psychological approach is essential, for example, non-epileptic attack disorder.

The nature of the conditions referred to this specialty will continue to be determined by the perceptions of the referring agents. How neuropsychiatry percetves mental illness rematns the fundamental princtple underlying its uniqueness and distinctiveness. It is suggested that future studies should assess the therapeutic interventions involved in neuropsychiatric practice which will determine whether this spectalty is merely a different philosophical approach to psychiatry or whether it is a distincttve discipline in its own right.

\section{References}

Cusamics, J. L. \& HzonRTY, A. (1994) Neurology, poychlatry and neuropoychiatry. Neurology, 44, 209-213.

LssianN, W. A. (1992) What is neuropoychlatry? Journal of Neurology, Newrosurgery and Psychiatry. 86. 983-985.

Rennolds, E. H. \& Trmals, M. R. (eds) (1989) The Bridge between Neurology and Poychlatry. Edinburgh: Chunchill Lutrgastone.

Bruce D. M. Scheepers, Senior Registrar in Neuropsychiatry: Jonathan M. Bird, Consultant Neuropsychiatrist; and Daniel G. Rogers, Consultant Neuropsychiatrist, Burden Neurological Hospttal, Stoke Lane, Stapleton, Bristol BS16 19T 